\title{
Determination and evaluation of biogas and methane productions of vegetable and fruit wastes with Hohenheim Batch Test method
}

\author{
Ali Aybek, Serdar Üçok \\ (Faculty of Agriculture, Department of Biosystems Engineering, KahramanmarasSutcu Imam University, Kahramanmaras, Turkey)
}

\begin{abstract}
Nowadays, biogas technology applications are gradually increasing worldwide due to the economic and environmental benefits. Many researches and studies related to the determination of the biogas potential of organic waste materials have been carried out in the recent years. Studies to determine the specific methane potential of organic waste materials have a great importance for both design and economical operation of the biogas plants. Energy potential that will be recovered from organic wastes is substantial in Turkey. Thanks to biogas plants gathering vegetable-fruit wastes and other organic wastes are planned to produce significant amount of renewable energy in Turkish markets. Owing to the use of organic wastes, the disposal of waste as well as energy production, soil, water and air pollution in terms of environmental protection are also minimized. On the other hand, the organic wastes produced from plants can also be utilized as fertilizer in vegetable production. In this study, the cumulative biogas and methane production of vegetable and fruit wastes were experimentally determined with HBT (Hohenheim Batch Test) method. Biogas and methane yields of vegetable and fruit wastes were found as $0.54-0.73 \mathrm{Nm}^{3} /\left(\mathrm{kg}\right.$ ODM) and $0.29-0.37 \mathrm{Nm}^{3} /(\mathrm{kg}$ ODM $)$, respectively. The highest value of the cumulative specific methane production was tomato wastes $\left(0.37 \mathrm{Nm}^{3} /(\mathrm{kg}\right.$ ODM $\left.)\right)$, and the lowest value was lettuce wastes $\left(0.29 \mathrm{Nm}^{3} /(\mathrm{kg}\right.$ ODM $\left.)\right)$, as well. The average cumulative specific methane production values of mixed vegetable and fruit wastes are determined as $0.34 \mathrm{Nm}^{3} /(\mathrm{kg}$ ODM $)$.
\end{abstract}

Keywords: biogas, methane production, Hohenheim Batch Test, vegetable and fruit wastes, renewable energy, Turkey

DOI: $10.25165 /$ j.ijabe.20171004.2864

Citation: Aybek A,Üçok S. Determination and evaluation of biogas and methane productions of vegetable and fruit wastes with Hohenheim Batch Test method Int J Agric \& Biol Eng, 2017; 10(4): 207-215.

\section{Introduction}

Energy management and control having gained unprecedented significance in modern age are widely recognized as one salient criterion of welfare and development. In parallel with the recent boost in human population, there has been a corresponding rise in the global demand for energy. As a consequence of the latest advancements in technology and the gradual

\section{Received date: 2016-09-23 Accepted date: 2017-03-05}

Biographies: Ali Aybek, Associate Professor, research interests: agricultural machinery management agricultural tractors, agricultural ergonomics, biogas, Email: aaybek@ksu.edu.tr.

* Corresponding author: Serdar Üçok, Research Assistant, research interests: renewable energy sources, biomass, biogas. The faculty of Agriculture, Biosystem Engineering, Kahramanmaraş Sütçü İmam University, Turkey. Tel: +903442802070, Email: sucok@ksu.edu.tr. depletion of fossil fuels, there has been a surge of attention towards renewable energy resources as the novel ways of energy procurement.

Renewable energy resources are termed as alternative fossil energy resources and have been naturally extracted from the energy-flow already present in our natural habitat. The most salient renewable energy resources are listed respectively as the sun, wind, water, geothermal and biomass ${ }^{[1]}$.

Among such renewable energy resources, particularly biomass technology draws much attention by virtue of the latest incentives. Biomass can be construed as the wood and other plants or any given animal wastes that can burn directly or can be converted to fuel ${ }^{[2]}$. In a different saying, biomass is a biogenic and non-fossil organic material mass. Its origin can be as diversified as agriculture and forest products, vegetable wastes, animal 
wastes, marine plants, industrial and domestic wastes and biomass that is originated from such resources is recognized as an environmentally-friendly, renewable and local energy resource capacious enough to meet the economic needs $^{[3-5]}$. A wide range of fuel types such as bioethanol, biogas, biodiesel and wood block can be generated from biomass ${ }^{[6]}$.

Biogas production from biomass resources is the most convenient and effective utilization method aside from direct burning. Led by China and India, this has been a widely-popular method applied in various countries including Thailand, the Philippines, Korea, Switzerland, the USA and Germany. Plants that are grown via agricultural activities or that remain as wastes; organic wastes disposed by humans; animal manures; molasses and fruit pulps formed as a result of confectionery and food industry operations; treatment sludges; wastes emitted from confectionery industry; paper industry wastes; abattoir wastes and other relevant organic materials are stuck into an anaerobic environment and disposed by the bacteria as a result of all the biochemical changes. As a consequence of this process, the biogas of which ingredients consist of $\mathrm{CH}_{4}, \mathrm{CO}_{2}, \mathrm{H}_{2} \mathrm{~S}$, ammoniac, nitrogen, hydrogen and water vapor is structured ${ }^{[7]}$. Biogas is procured at the end of the anaerobic fermentation process of organic wastes in the facilities ${ }^{[8,9]}$ and it is a colorless, odourless, lighter-than-air form burnt with a bright-blue flame and it preserves circa 50\%-75\% $\mathrm{CH}_{4}, 30 \%-60 \% \mathrm{CO}_{2}, 0-3 \% \mathrm{H}_{2} \mathrm{~S}$ and trace amounts of nitrogen and hydrogen in relation to the organic materials in its combination ${ }^{[10,11]}$. Biogas density is $0.83 \mathrm{~g} / \mathrm{L}$; its approximate octane number is 110; the combustion temperature is $700^{\circ} \mathrm{C}$, and flame temperature is $870^{\circ} \mathrm{C}$. Biogas compound varies with respect to the type of its original organic material and fermentation method ${ }^{[12]}$.

Utilization of organic root wastes (animal wastes, vegetable wastes, urban and industrial wastes) by biogas technology not only provides energy production but it also effectively disposes the wastes; hence it is a popular way of minimizing soil, water and air pollution towards the aim of maximizing environmental protection ${ }^{[13]}$. Furthermore, organic wastes produced in plants are utilized as fertilizers for growing vegetables.
Effective assessment of organic wastes is important, not only in terms of prevention of environmental pollution but also in terms of creation of added value. Today, production of biogas from organic wastes is an important subject of application. There is an important potential for organic waste in Turkey. As of 2014, the total amount of solid waste is about 28 million tons ${ }^{[14]}$. When about $1 / 3$ of these solid wastes can be assessed on landfills, the rest are disposed of in the municipal garbage ${ }^{[15,16]}$. Considering that the household waste composition is $65 \%$ organic, $23 \%$ ash-slag and $12 \%$ recoverable ${ }^{[16]}$ has approximately 18.2 million tons of solid organic waste per year in Turkey. Twenty percent of vegetable and fruit production is waste in agricultural production ${ }^{[17]}$. According to the data of 2015 , total vegetable and fruit production are 50 million tons in Turkey ${ }^{[18]}$. According to this, annual amount of vegetables and fruit waste are 10 million tons in Turkey. Most of these wastes are left to the nature. Biogas production from these renewable sources could be an important application for Turkey that imports $3 / 4$ of the energy it uses.

In present study, the objective has been to investigate vegetable and fruit wastes that have potential application areas in biogas facilities. To achieve that objective, vegetable-fruit markets and biogas production potentials of wastes in the open markets have been determined. In line with this common objective, market wastes have been collected, dried and grinded in Hohenheim University, Agricultural Machinery and Bioenergy Laboratory. Next, dry matter and organic material analyses were conducted on the grinded wastes. Subsequently, in the biogas measurement laboratory stationed within the relevant unit, Hohenheim Batch Test (HBT) method was applied to measure experimentally the specific methane and biogas production values. It is deemed that this experimental study aiming to detect methane and biogas production potentials of vegetable-fruit wastes via HBT method $^{[19]}$ is a pioneer work in Turkey.

\section{Materials and Methods}

\subsection{Materials}

\subsubsection{Vegetable and fruit wastes}

Within the scope of present study, vegetable and fruit 
wastes were collected from open landfill areas in wholesale markets and district bazaars within Kahramanmaraş Metropolitan Municipality. The interviews conducted with wholesale-market managers pointed out that during summer season an average of $30 \mathrm{t} / \mathrm{d}$ (3 trucks), and during winter months an average of 10 t/d (1 truck) vegetable and fruit wastes were produced.

\subsubsection{Test unit}

This research was executed in Stuttgart Hohenheim University, Agricultural Machinery and Bioenergy Engineering Biogas Research Laboratory. Methane and biogas yield was measured by laboratory-scaled "Hohenheim Biogas Test method" ${ }^{[19]}$ as per the standard VDI Guideline $4630^{[20]}$. In HBT method, the absorber consists of $100 \mathrm{~mL}$ glass tubes. Figure 1 presents a patented HBT unit. The unit is made up of: shift and leakage tool, $1 \mathrm{~mL}$ division, gas chamber, space for gas analysis, clamp, glass syringe, fermentation material, piston and tubule. In the front part of this system, there is a folding clamp for gas measurement and to be protective against air ingress. To prevent anaerobic spoilage and air inlet, grease oil or vaseline is administered between the piston and syringe. In this method there is no requirement for gas sample tube as an extra tool.

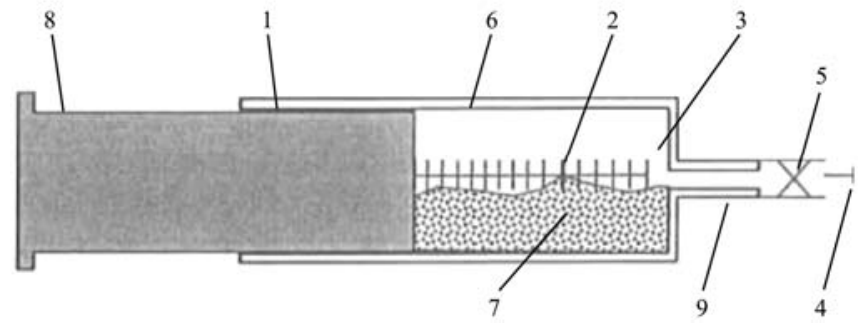

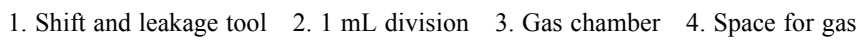
analysis 5. Clamp 6. Glass syringe 7. Fermentation material 8. Piston 9. Tubule

Figure 1 Syringe of HBT

In regular gas measurements biogas is accumulated in the gas chamber. By establishing a connection via a special pipe between the measurement tool and syringes to make measurements, it is possible to stop gas loss. One hundred and twenty nine units of glass syringes are positioned into a cabinet termed as incubator (Figure 2) and rotating inside a circle which has 129 divisions within. Inside the cabinet there is a rotor circulating the indoor temperature at equal levels ${ }^{[20]}$.

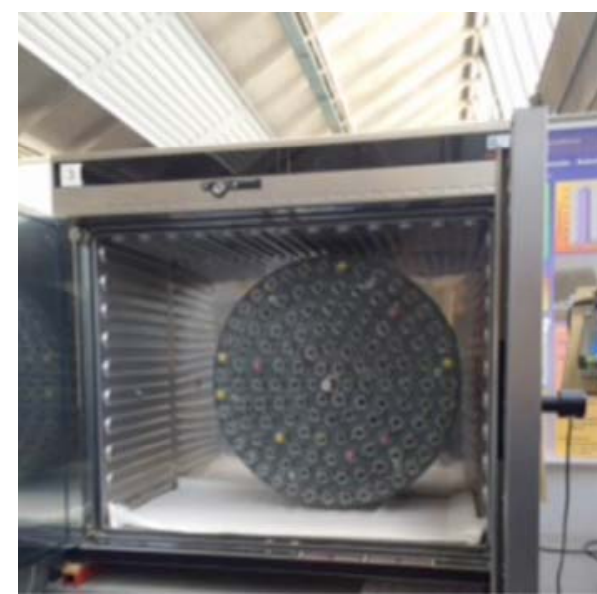

Figure 2 Interior image of incubator

\subsubsection{Inoculum}

Inoculum is a liquid+solid phase mixture and procured from three different biogas plants operating under a mesopholic $\left(37^{\circ} \mathrm{C}-40^{\circ} \mathrm{C}\right)$ environment in Stuttgart city, Germany.

2.1.4 Methane measurement apparatus and calibration tube

Volumetric measurement of methane gas was conducted via infrared-spectrometric methane-sensor 'Advanced Gasmitter' (Pronova Analysetechnik, Berlin, Germany) apparatus. Prior to initiating methane measurements of vegetable and fruit wastes, calibration tube was activated to inspect the methane measurement apparatus.

\subsection{Methods}

\subsubsection{Experimental procedure}

Investigated vegetable and fruit wastes were selected circa one kilogram for every single fresh material and placed into drying oven between $50^{\circ} \mathrm{C}$ to $60^{\circ} \mathrm{C}$. As per the effective standard ${ }^{[20]}$ dried vegetable and fruit wastes (cucumbers, lettuce, pepper, tomatoes, onions, mixed vegetables-fruits, peach and apple) were sifted through $1 \mathrm{~mm}$ sieve and then they were grinded. Additionally, in order to compare biogas yields that might accrue in different dimension wastes with respect to standard values of all the investigated wastes, $3 \mathrm{~mm}$ dimensional grinding procedure was implemented on apple, peach and mixed fruits-vegetables. Three samples were taken from each of the grinded material and each $0.2 \mathrm{~g}$ sample was weighed on a micro scale before being administered into $100 \mathrm{~mL}$ glass syringes with the help of special spoons. Next, syringe samples were put into the divisions inside 
this incubator. Correspondingly, for the comparison group samples, three units of inoculum syringe which were prepared by a buret with the capacity of holding $30 \mathrm{~mL}$ inoculum for each, were also put into the divisions inside this incubator.

As per the effective standard, prior to administering weighed samples into syringes, piston of the syringe was ejected and plastic clips were mounted into the silicon pipes at the end point of the injector and were used to conduct gas transfer. To prevent gas leakage during the analysis, injector pistons were covered with vaseline by leaving a three finger space from the bottom and top sections. Later, glass syringe pistons were inserted and clips were closed to make the system ready for operation. After administrating inoculum into the syringes, there were horizontally located into a $37^{\circ} \mathrm{C}$ incubator. To warrant that materials inside the syringes were placed into syringe holes in the circle within the incubator, it was enabled to rotate the circle by a speed of $10 \mathrm{~d} \mathrm{~d}^{-1}$. Prior to the incubator processes methane measurement apparatus used to determine methane content was calibrated via a calibration tube $\left(60.5 \% \mathrm{CH}_{4}\right)$. The objective in calibration is to confirm that measured gas can meet the standard conditions $\left(0^{\circ} \mathrm{C}\right.$ and $\left.1013 \mathrm{hPa}\right)$. Measurements continued for $35 \mathrm{~d}$ in row. For the first $6 \mathrm{~d}$, measurements were repeated every $6 \mathrm{~h}$; in the subsequent days, there were conducted within $8 \mathrm{~h}$ and $12 \mathrm{~h}$ intervals so as to detect the ratio of methane yield in each single sample. Methane values were measured once $20 \mathrm{~mL}$ level was attained in glass syringes by using a methane-reading apparatus ${ }^{[20]}$.

To measure produced biogas, methane content and cumulative methane gas volume were employed as per standard $^{[20]}$.

\subsubsection{Inoculum preparation}

The mixture was prepared in a tank located in Hohenheim University biogas laboratory. After eject the mixture under $37^{\circ} \mathrm{C}$ temperature inside a $300 \mathrm{~L}$ tank to stabilize its content $18 \mathrm{~g}$ spica core, $18 \mathrm{~g}$ corn, $10 \mathrm{~g}$ soya, $12 \mathrm{~g}$ colza oil and specific amount of water was added every day to the core.

\subsubsection{Dry matter and organic material analysis}

Dry matter and organic material analyses were employed as per standard ${ }^{[21]}$.

\subsubsection{Methane measurement}

Methane values contained by the biogas filled with vegetable and fruit wastes were volumetrically measured via the infrared-spectrometric methane-sensor 'Advanced Gasmitter' (Pronova Analysetechnik, Berlin, Germany) measurement apparatus.

\subsubsection{Data collection and assessment}

Investigated vegetable and fruit wastes were collected and dried during 2015 summer season. The dried materials were grinded in desired dimensions as per the standard in Agricultural Machinery and Bioenergy Engineering Biogas Research Laboratory, Hohenheim University, Stuttgart, Germany, and dry matter (DM), organic dry matter (ODM), methane and biogas yields of every single material were specified. Methane productions of vegetable and fruit wastes were repeated three times which in effect provided an approximate value. Findings obtained from this research were transferred to the tables and figures before offering any suggestions.

\section{Findings and discussion}

In this part of the research, DM and ODM ratios, biogas production and methane ratios in the biogas of the cucumber, lettuce, pepper, tomatoes, onions, mixed vegetables-fruits, peach and apple wastes purchased from raw vegetables and fruit open market in Kahramanmaraş Metropolitan Municipality were measured. In biogas production for each single material $35 \mathrm{~d}$ lasting measurement was conducted in three different glass syringes and for the contrast group, these were administered into separate glass syringes containing inoculum.

\subsection{DM and ODM ratios of vegetable-fruit wastes}

DM and ODM ratios of test samples prepared from vegetable and fruit wastes are as demonstrated in Table 1. Inside this mixed vegetable and fruit samples prepared in dimension of $1 \mathrm{~mm}$ as per the test standards, DM ratio equals to approximate $86 \%$, ODM ratio equals to $87 \%$, whereas in dimension of $3 \mathrm{~mm}$ for mixed vegetable and fruit wastes samples prepared to measure the values of different materials, DM ratio equals to approximate $85 \%$, 
ODM ratio equals to $87 \%$. In these investigated, the highest DM ratio in $1 \mathrm{~mm}$ samples was in lettuce wastes $(89.9 \%)$, the lowest was in apple wastes $(81.1 \%)$, whilst the highest ODM ratio was in apple wastes (95.9\%), the lowest was in lettuce wastes $(69.7 \%)$. The highest samples DM ratio in $3 \mathrm{~mm}$ was in mixed vegetable and fruit wastes $(84.6 \%)$, the lowest was in apple wastes $(81.1 \%)$, whilst the highest ODM ratio was in apple wastes $(95.9 \%)$, and the lowest was in mixed vegetable and fruit wastes $(87.2 \%)$ (Table 1). Gül ${ }^{[22]}$ in his research titled as 'Determining biogas production potential of vegetable and fruit wastes' measured that DM ratios in the mixed vegetable and fruit wastes measured in Ankara city were $82.3 \%-89.9 \%$, whilst ODM ratios were $73.3 \%-80.7 \%$. The reasons for the discrepancy in these ratios are that those wastes were collected during summer and winter seasons; there was a chemical differentiation; waste mixtures were differently rationed and vegetable-fruit variety was not identical.

Table 1 DM and ODM rates of existing vegetable and fruit

\begin{tabular}{cccc}
\multicolumn{3}{c}{ wastes } \\
\hline Vegetables-fruit wastes & Dimension & DM/\% & ODM/\% \\
\hline Cucumber & & 84.9 & 85.4 \\
Lettuce & & $\mathbf{8 9 . 9}$ & 69.7 \\
Pepper & & 86.2 & 91.9 \\
Tomato & $1 \mathrm{~mm}$ & 84.9 & 88.7 \\
Onion & & 86.1 & 92.5 \\
Apple & & 81.1 & $\mathbf{9 5 . 9}$ \\
Peach & & 82.6 & 92.6 \\
Mixed vegetables-fruit wastes & & 86.1 & 87.4 \\
\hline & Mean & 85.23 & 88.1 \\
\hline Peach & & 82.6 & 92.6 \\
Apple & $3 \mathrm{~mm}$ & 81.1 & 95.9 \\
Mixed vegetables-fruit wastes & & 84.6 & 87.2 \\
\hline & Mean & 82.77 & 91.9 \\
\hline
\end{tabular}

\subsection{Methane production values of vegetable-fruit}

\section{wastes}

In this study, firstly, biogas-methane production of inoculum was measured as per the standard ${ }^{[20]}$ to ascertain biogas formation efficiency of the anaerobic environmental conditions. Next, methane production of the investigated vegetable and fruit wastes was measured. Investigated vegetable and fruit wastes were prepared (grinded) in two different dimensions before detecting their methane production. One dimension was taken as the standard dimension $(1 \mathrm{~mm})$; the other was taken as
$3 \mathrm{~mm}$. As the vegetable-fruit wastes, the $1 \mathrm{~mm}$ cucumber, lettuce, pepper, tomatoes, onions, peach, apple and mixed vegetable-fruit whilst the $3 \mathrm{~mm}$ peach, apple and mixed vegetables-fruits were investigated. The mean values of inoculum were computed for methane production.

Time dependent mean cumulative methane production values of all the investigated vegetable-fruit wastes and inoculum are as manifested in Figure 3.

As per the experiment, the standard cumulative specific methane production to be formed in the inoculum must equate to $0-0.1 \mathrm{Nm}^{3} /(\mathrm{kg} \mathrm{ODM})^{[23]}$. In this study, maximum cumulative specific methane production formed in the inoculum is measured as $0.09 \mathrm{Nm}^{3} /(\mathrm{kg}$ ODM). Time dependent mean cumulative methane production in the inoculum starts on the $1^{\text {st }}$ day, and increases each subsequent day before reaching its maximum value on the 30-35 d (Figure 3). The reason explaining the low methane value in the inoculum at the beginning is that more time is required for anaerobic (oxygenless) degradation.

In the cumulative methane production of all the investigated vegetable-fruit wastes, there has been a linear increase on the 1-15 d, but the speed in the increase gradually lowered between 15-35 d and reached maximum value on the $35^{\text {th }}$ day. The highest Cumulative specific methane production is in tomato wastes $\left(0.37 \mathrm{Nm}^{3} /(\mathrm{kg}\right.$ ODM $)$ and the lowest is in lettuce wastes $\left(0.34 \mathrm{Nm}^{3} /(\mathrm{kg}\right.$ ODM)) (Figure 3).

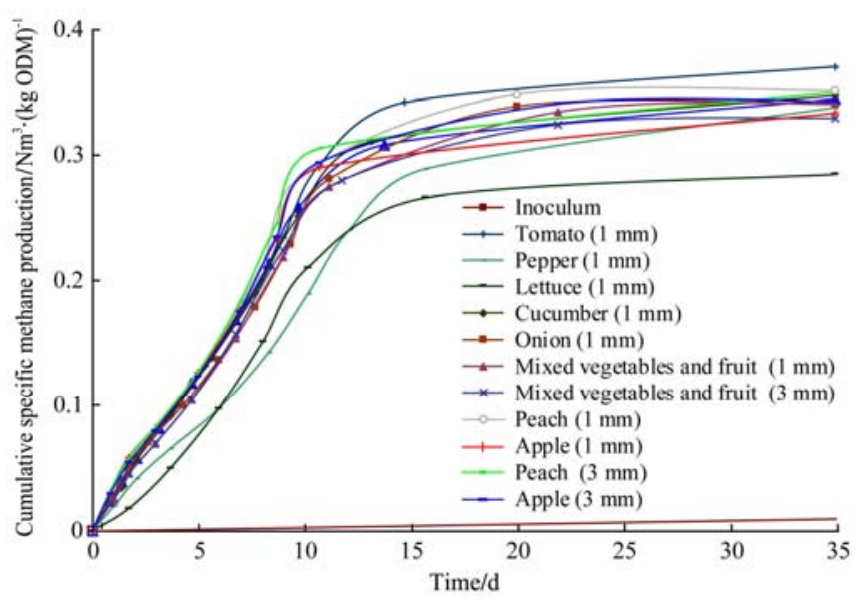

Figure 3 Average cumulative methane production of all wastes

\subsection{Methane content ratios and biogas production} values in vegetable-fruit wastes

Methane contents and biogas production values of the biogas of the vegetable-fruit wastes prepared as $1 \mathrm{~mm}$ 
and $3 \mathrm{~mm}$ are displayed in Table 2. Accordingly, the maximum methane content of biogas is in $1 \mathrm{~mm}$ cucumber, lettuce, pepper and tomato wastes (methane ratio of each single waste is 54\%). For both dimensions (1 $\mathrm{mm}$ and $3 \mathrm{~mm}$ ), the lowest methane ratio (49\%) consists of apple wastes. Methane ratio of the biogas is equal to $53 \%$ form $1 \mathrm{~mm}$ mixed vegetable-fruit wastes, and is equal $52 \%$ from $3 \mathrm{~mm}$ mixed vegetable-fruit wastes.

Table 2 Methane content and biogas production of vegetables and fruit wastes

\begin{tabular}{cccc}
\hline $\begin{array}{c}\text { Vegetables-fruit } \\
\text { wastes }\end{array}$ & Dimension & $\begin{array}{c}\text { Methane content } \\
/ \%\end{array}$ & $\begin{array}{c}\text { Biogas production } \\
\left(\mathrm{Nm}^{3} \cdot(\mathrm{kg} \mathrm{ODM})^{-1}\right.\end{array}$ \\
\hline $\begin{array}{c}\text { Cucumber } \\
\text { Lettuce }\end{array}$ & 54 & 0.645 \\
Pepper & 54 & 0.536 \\
Tomato & 54 & 0.643 \\
Onion & $1 \mathrm{~mm}$ & 54 & 0.692 \\
Apple & 51 & 0.678 \\
Peach & & 49 & 0.686 \\
Mixed vegetables- & 50 & 0.708 \\
fruit wastes & & 53 & 0.651 \\
\hline Peach & & 49 & 0.706 \\
Apple & 48 & 0.726 \\
Mixed vegetables- & $3 \mathrm{~mm}$ & 52 & 0.637 \\
fruit wastes & & &
\end{tabular}

The highest biogas production of vegetable-fruit wastes is in peach wastes with dimensions of $3 \mathrm{~mm}(0.73$ $\mathrm{Nm}^{3} /(\mathrm{kg}$ ODM $)$ ), and lowest is in lettuce wastes of $1 \mathrm{~mm}$ $\left(0.54 \mathrm{Nm}^{3} /(\mathrm{kg}\right.$ ODM $\left.)\right)$. Biogas production of the mixed fruit-vegetable wastes were $0.65 \mathrm{Nm}^{3} /(\mathrm{kg}$ ODM) for samples with dimensions of $1 \mathrm{~mm}$ and $0.64 \mathrm{Nm}^{3} /(\mathrm{kg}$ ODM) for samples with dimensions of $3 \mathrm{~mm}$ (Table 2).

\subsection{Comparison of methane and biogas productions of vegetable-fruit wastes}

Mean values of methane and biogas production of the investigated vegetable-fruit wastes are as seen in Figure 4. The highest biogas production is measured in peach wastes $\left(0.726 \mathrm{Nm}^{3} /(\mathrm{kg} \mathrm{ODM})\right)$ and the highest methane production in tomato wastes $\left(0.37 \mathrm{Nm}^{3} /(\mathrm{kg}\right.$ ODM $\left.)\right)$ tracked by apple and cucumber respectively (Figure 4).

\subsection{Literature review for the biogas production of vegetable-fruit wastes}

As detected in relevant literary studies and in present study likewise, comparison of the biogas production produced from mixed vegetable-fruit wastes in specific mesophilic environmental conditions $\left(37^{\circ} \mathrm{C}-40^{\circ} \mathrm{C}\right)$ are as manifested in Table 3.

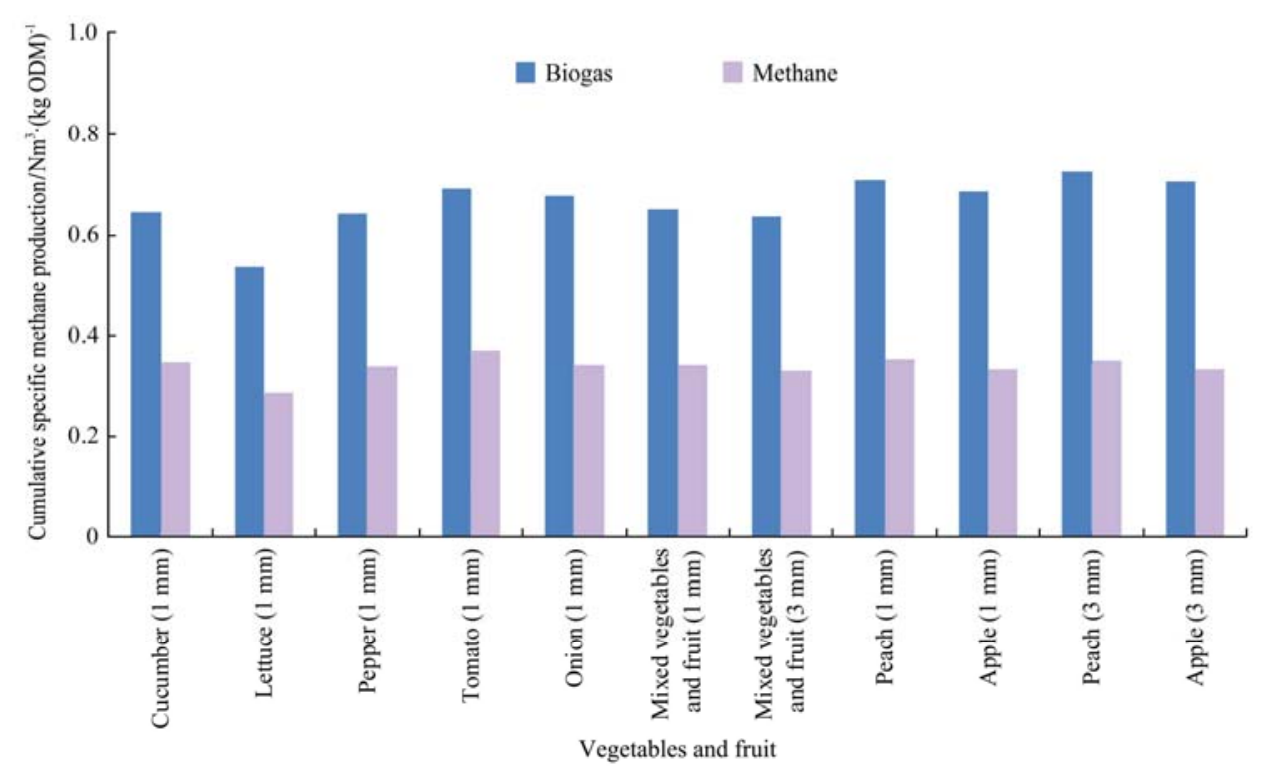

Figure 4 Comparison of methane and biogas productions of vegetable and fruit wastes

Biogas produced via anaerobic degradation of the mixed vegetable-fruit wastes were measured by Lane ${ }^{[24]}$ as $0.429-0.568 \mathrm{Nm}^{3} /(\mathrm{kg} \mathrm{ODM})$, by Prema et al. ${ }^{[25]}$ as $0.5-0.6 \mathrm{Nm}^{3} /(\mathrm{kg}$ ODM $)$, by Mtz.-Viturtia et al. $^{[26]}$ as $0.2-0.63 \mathrm{Nm}^{3} /(\mathrm{kg}$ ODM $)$, by Bouallagui et al. ${ }^{[27]}$ as $0.707 \mathrm{Nm}^{3} /(\mathrm{kg}$ ODM $)$, by Qiao et al..$^{[28]}$ as 0.443 $\mathrm{Nm}^{3} /(\mathrm{kg}$ ODM $)$. In a study conducted by Gül ${ }^{[22]}$, the theoretical biogas productions of vegetable-fruit wastes was $\quad 0.27-0.34 \quad \mathrm{Nm}^{3} /(\mathrm{kg} \quad \mathrm{ODM}) . \quad$ Via anaerobic degradation biogas production procured from corn silage was $0.655 \mathrm{Nm}^{3} /(\mathrm{kg} \mathrm{ODM})^{[29]}$, biogas production procured from animal manure was $0.471 \mathrm{Nm}^{3} /(\mathrm{kg} \text { ODM })^{[30]}$. In this experimental study (via anaerobic degradation), biogas production of the mixed vegetable-fruit was 
$0.651 \mathrm{Nm}^{3} /(\mathrm{kg}$ ODM $)$ for $1 \mathrm{~mm}$ samples, 0.637 $\mathrm{Nm}^{3} /(\mathrm{kg}$ ODM) for $3 \mathrm{~mm}$ samples (Table 3$)$.

Table 3 Comparison with the literature of biogas productions

\begin{tabular}{lccc}
\hline \multicolumn{1}{c}{ Researchers } & Waste materials & $\begin{array}{c}\text { Determination } \\
\text { method }\end{array}$ & $\begin{array}{c}\text { Biogas } \\
\mathrm{Nm}^{3} \cdot(\mathrm{kg} \mathrm{ODM})^{-1}\end{array}$ \\
\hline Lane $^{[24]}$ & Mixed vegetables-fruit & Experimental & $0.429-0.568$ \\
Prema et al $^{[25]}$ & Mixed vegetables-fruit & Experimental & $0.5-0.6$ \\
Mtz.-Viturtia et al. $^{[26]}$ & Mixed vegetables-fruit & Experimental & $0.2-0.63$ \\
Bouallagui et al. $^{[27]}$ & Mixed vegetables-fruit & Experimental & 0.707 \\
Qiao et al. $^{[28]}$ & Mixed vegetables-fruit & Experimental & 0.443 \\
Gül $^{[22]}$ & Mixed vegetables-fruit & Theoric & $0.27-0.34$ \\
Hutnan et al. & Maize silaje & Experimental & 0.655 \\
Frauke et al. $^{[30]}$ & $\quad$ Manure & Experimental & 0.471 \\
This research & Mixed vegetables-fruit & Experimental & $\mathbf{0 . 6 5 1}$ \\
& $(1 \mathrm{~mm})$ & & \\
This research & Mixed vegetables-fruit & Experimental & 0.637 \\
\hline
\end{tabular}

In this study, it has been witnessed that biogas productions procured from fruit-vegetable wastes are higher than that from animal manures but equal to the biogas production procured from corn silage, which is indicative of the fact that biogas productions procured from fruit-vegetable wastes are rather significant.

Findings of the present and previous studies conducted on the significance of biogas productions of vegetable-fruit wastes, demonstrated that the most effective biogas production can only be feasible under mesophilic conditions. Pretreatment of the vegetable and fruit wastes, temperature increment and adding extra materials such as clays and fertilizers into vegetable and fruit wastes could, as has been verified in relevant studies, further increment biogas efficiency. It can also reasonably be argued that dimensional differences of the materials, the ratios of chemical composition are also effective on the methane and biogas production of vegetable and fruit wastes.

\subsection{Statistical comparison of methane and biogas production of vegetable-fruit wastes}

Statistical differences of the procured methane and biogas productions of $1 \mathrm{~mm}$ vegetable-fruit wastes are as seen in Table 4 and variance analyses are as exhibited in Table 5. The highest methane production from $1 \mathrm{~mm}$ vegetable-fruit wastes was in tomato wastes and the lowest in lettuce wastes. The highest biogas production procured from waste materials was in peach wastes and the lowest in lettuce wastes (Table 4). Statistical comparison indicated that methane and biogas production of the vegetable-fruit wastes with dimensions of $1 \mathrm{~mm}$ are significant $(p<0.01)$ as seen in Table 5.

Statistical differences of the procured methane and biogas productions of $3 \mathrm{~mm}$ vegetable-fruit wastes are as seen in Table 6 and variance analyses are as exhibited in Table 7. The highest biogas production from $3 \mathrm{~mm}$ vegetable-fruit wastes was measured in mixed fruit-vegetable wastes and the lowest in apple wastes (Table 7). At the end of this statistical comparison, it was identified that biogas production of $3 \mathrm{~mm}$ vegetablefruit wastes was significant $(p<0.01)$ whilst its methane production were relatively insignificant (Table 7).

There was no statistically significant dimensional difference of $1 \mathrm{~mm}$ and $3 \mathrm{~mm}$ vegetable-fruit wastes in term of the methane and biogas production values (Table 8).

\begin{tabular}{|c|c|c|c|}
\hline Dimension & Wastes & $\begin{array}{l}\text { Methane Production** } \\
/ \mathrm{Nm}^{3} \cdot\left(\mathrm{kg} \mathrm{ODM}^{-1}\right.\end{array}$ & $\begin{array}{l}\text { Bogas Production** } \\
/ \mathrm{Nm}^{3} \cdot\left(\mathrm{kg} \mathrm{ODM}^{-1}\right.\end{array}$ \\
\hline \multirow{8}{*}{$1 \mathrm{~mm}$} & Apple & $0.335 \mathrm{c}$ & $0.687 \mathrm{ab}$ \\
\hline & Peach & $0.353 \mathrm{~b}$ & 0.708 a \\
\hline & $\begin{array}{c}\text { Mixed } \\
\text { vegetables-fruit }\end{array}$ & $0.342 \mathrm{bc}$ & $0.650 \mathrm{c}$ \\
\hline & Cucumber & $0.349 \mathrm{bc}$ & $0.645 \mathrm{c}$ \\
\hline & Lettuce & $0.286 \mathrm{~d}$ & $0, .36 \mathrm{~d}$ \\
\hline & Pepper & $0.339 \mathrm{bc}$ & $0.644 \mathrm{c}$ \\
\hline & Tomato & 0.372 a & $0.692 \mathrm{ab}$ \\
\hline & Onion & $0.342 \mathrm{bc}$ & $0.679 \mathrm{~b}$ \\
\hline
\end{tabular}

Note: Means followed by different letters in the same row are significantly different; $* * p<0.01$.

Table 5 Variance analysis table of methane productions from $1 \mathrm{~mm}$ vegetable and fruit wastes

\begin{tabular}{ccccccc}
\hline \multirow{2}{*}{ Products } & Variations source & $d f$ & $S S$ & $M S$ & $F$-value & Possibility \\
\hline \multirow{3}{*}{ Methane } & Wastes & 7 & 0.013 & 0.002 & 26.440 & $0.000^{* *}$ \\
& Error & 16 & 0.001 & 0.000068 & & \\
& General & 24 & 2.784 & & & \\
\multirow{2}{*}{ Biogas } & Wastes & 7 & 0.06 & 0.009 & 48.588 & $0.000^{* *}$ \\
& Error & 16 & 0. & 0.000 & & \\
& General & 24 & 10.361 & & & \\
\hline
\end{tabular}

Note: $d f$ : Degrees of fredoom, $S S$ : Sum of square, $\overline{\text { MS: Mean of square, }}$ $* * p<0.01$.

Table 6 Methane and biogas productions from 3 mm vegetable and fruit wastes

\begin{tabular}{|c|c|c|c|}
\hline Dimension & Wastes & $\begin{array}{l}\text { Methane Production } \\
\\
/ \mathrm{Nm}^{3} \cdot(\mathrm{kg} \mathrm{ODM})^{-1}\end{array}$ & $\begin{array}{l}\text { Biogas Production** } \\
/ \mathrm{Nm}^{3} \cdot\left(\mathrm{kg} \mathrm{ODM}^{-1}\right.\end{array}$ \\
\hline \multirow{3}{*}{$3 \mathrm{~mm}$} & Apple & 0.344 & $0.687 \mathrm{a}$ \\
\hline & Peach & 0.353 & $0.708 \mathrm{a}$ \\
\hline & $\begin{array}{c}\text { Mixed } \\
\text { vegetables-fruit }\end{array}$ & 0.330 & $0.638 \mathrm{~b}$ \\
\hline
\end{tabular}

Note: ni: not important, ${ }^{* *} p<0.01$. 
Table 7 Variance analysis table of methane productions from $3 \mathrm{~mm}$ vegetable and fruit wastes

\begin{tabular}{lcccccc}
\hline \multirow{2}{*}{ Products } & $\begin{array}{c}\text { Variations } \\
\text { source }\end{array}$ & $d f$ & $S S$ & $M S$ & $F$-value & Possibility \\
\hline \multirow{3}{*}{ Methane } & Wastes & 2 & 0.001 & 0.000 & 3.419 & $0.102^{n i}$ \\
& Error & 6 & 0.001 & 0.000 & & \\
\hline \multirow{2}{*}{ Biogas } & General & 9 & 1.056 & & & \\
& Wastes & 2 & 0.008 & 0.004 & 12.938 & $0.007^{* *}$ \\
& Error & 6 & 0.002 & 0.000 & & \\
\hline
\end{tabular}

Note: $d f$ : Degrees of freedoom, $S S$ : Sum of square, $M S$ : Mean of square; ni: not important; ** $p<0.01$.

Table 8 Variance analysis table of methane and biogas productions as dimensional from $1 \mathrm{~mm}$ and $3 \mathrm{~mm}$ vegetable and fruit wastes

\begin{tabular}{ccccccc}
\hline $\begin{array}{c}\text { Methane/ } \\
\text { Biogas }\end{array}$ & $\begin{array}{c}\text { Variations } \\
\text { source }\end{array}$ & $d f$ & SS & $M S$ & F-value & Possibility \\
\hline \multirow{3}{*}{ Methane } & Wastes & 1 & 0.000055 & 0.00005 & 0.050 & $0.827^{n i}$ \\
& Error & 14 & 0.002 & 0.000 & & \\
& General & 18 & 2.119 & & & $0.576^{n i}$ \\
Biogas & Wastes & 1 & 0.000084 & 0.000085 & 0.327 & \\
& Error & 14 & 0.004 & 0.000 & & \\
\hline
\end{tabular}

Note: $d f$ : Degrees of Fredoom, SS: Sum of Square, $M S$ : Mean of Square, ni: not important.

\section{Conclusions and suggestions}

The biogas production potentials of vegetable and fruit wastes were experimentally determined, the conclusions and suggestions can be outlined as below:

1) In samples with dimensions of $1 \mathrm{~mm}$, the highest DM ratio was in lettuce wastes (90\%), the lowest in apple wastes $(81.1 \%)$, whilst the highest ODM ratio was in apple wastes $(96 \%)$, the lowest in lettuce wastes $(70 \%)$.

2) In samples with dimensions of $3 \mathrm{~mm}$, the highest DM ratio was in mixed vegetable and fruit wastes $(85 \%)$, the lowest in apple wastes (81\%), whilst the highest ODM ratio was in apple wastes (96\%), the lowest in mixed vegetable and fruit wastes $(87 \%)$.

3) In the cumulative methane production of all vegetable-fruit wastes, there has been a linear increase on the 1-15 d, but the increasing rate gradually decreased between $15-35 \mathrm{~d}$ and reached maximum value on the $35^{\text {th }}$ day.

4) The highest methane production was measured in tomato waste $\left(0.37 \mathrm{Nm}^{3} /(\mathrm{kg}\right.$ ODM $\left.)\right)$ and the lowest methane production was observed in lettuce wastes $\left(0.34 \mathrm{Nm}^{3} /(\mathrm{kg}\right.$ ODM $\left.)\right)$.
5) Methane ratios of the wastes samples with dimensions of $1 \mathrm{~mm}$ and $3 \mathrm{~mm}$ were measured between 50\%-54\% and $48 \%-52 \%$, respectively.

6) The biogas production of $1 \mathrm{~mm}$ and $3 \mathrm{~mm}$ wastes was measured as $0.536-0.726 \mathrm{Nm}^{3} /(\mathrm{kg}$ ODM $)$ and $0.637-0.726 \mathrm{Nm}^{3} /(\mathrm{kg}$ ODM $)$ and these values hold significance in the studies.

7) At the end of conducted statistical comparison, it was manifested that of all the vegetable-fruit wastes with dimensions of $1 \mathrm{~mm}$ and $3 \mathrm{~mm}$, there was no statistically significant dimensional difference in term of the methane and biogas production values.

8) HBT method is an efficient and practical method to detect methane and biogas potential of organic materials.

In the light of procured findings and assessments, below-listed suggestions on the same topic can be listed:

1) Vegetable and fruit wastes have high biogas production potentials; hence they remain as vital materials for biogas facilities.

2) In Turkey which has high potential for vegetable and fruit wastes, it may be feasible to conserve critical amounts of energy biogas by setting biogas facilities.

3) In the event that these wastes are used for biogas, and the wastes could be utilized as organic fertilizers in agricultural processes.

4) By activating biogas process, the greenhouse gases $\left(\mathrm{CH}_{4}\right.$ and $\left.\mathrm{CO}_{2}\right)$ might be emitted to the atmosphere due to mismanaged storing of wastes could be prevented.

5) Through disposing the wastes odor density would be diminished and environmental problems might be alleviated.

6) Since there is high potential for organic material wastes in Turkey, determining the use ratio of the energy to be procured from such wastes and conducting studies on their environmental effects could further empower the database.

7) Anaerobic degradation process which is a common method in developed countries but not widely popular in Turkey could be employed to further benefit from vegetable and fruit wastes.

8) National-origin and environment-friendly energy can be generated by treating the organic wastes in biogas facilities. 


\section{Acknowledgments}

We would like to extend our deepest gratitude to the Rectorate of Kahramanmaraş Sütçü İmam University having rendered all the available means to achieve this study conducted within the context of BAP Researches, and we also would like to thank to Dr. Hans Oechsner and Dr. Annett Reinhardt-Hanisch who were kind enough to let us conduct research measurements and analyses in Hohenheim University, Agricultural Machinery and Bioenergy Laboratory.

\section{[References]}

[1] Deublein D, Steinhauser A. Biogas from waste and renewable resources. Wiley-VCH Verlag $\mathrm{GmbH} \& \mathrm{Co}$. KGaA, 2008.

[2] Fanchi J R. Energy in the 21st century. World Scientific Publishing Co. Pte. Ltd. 5 Toh Tuck Link, Singapore 596224, 2011.

[3] Anonymous. Renewable energy source, renewable energy source in Turkey. Environmental Foundation of Turkey, Edition No: 175, Ankara, 2006.

[4] Acaroğlu M. Alternative energy source. Nobel Edition No: 1253, Ankara, 2007.

[5] Öztürk H H. Renewable energy source and usage. Teknik Publisher, Ankara, 2008.

[6] Kapluhan E. A study of energy geography: Status of biomass energy usage in the world and Turkey. Journal of Marmara Geography, 2014; 30: 97-125.

[7] Akova İ. Renewable energy source. Nobel Edition No: 1294, Ankara, 2008.

[8] Christy P M, Gopinath L R, Divya D. A review on anaerobic decomposition and enhancement of biogas production through enzymes and micro organisms. Renew Sustain Energy Rev, 2014; 34: 167-173.

[9] Peyman A, Jeng S L, Wai S L, Chew T L. Potentional of biogas production from farm animal waste in Malaysia. Renewable and Sustainable Energy Reviews, 2016; 60: 714-723.

[10] Angelidaki I, Ellegaard L, Ahring B K. Application of the anaerobic digestion process. Advences in Biochemical Engineering/Biotechnology Biomethanation, 2003; 82: 189-194.

[11] Arkutman F. Wastewater treatment and treatment techniques. Science and Technique, 2003; 428: 42-52.

[12] Bayrakçeken H. Biogas production system design and implementation. Master thesis, Afyon Kocatepe University, Institute of Natural Sciences, Afyon. 2007.

[13] Onursal E, Ekinci K, Oechsner H. Biogas production potential of rose oil processing wastes and quail manure in Turkiye: Assessment by Hohenheim Batch Test. Journal of
Agricultural Machinery Science, 2011; 7(4): 393-398.

[14] The State Institute of Statistics, Prime Ministry, Republic of Turkey. Database statistics, münicipal waste. Ankara, State Institute of Statistics, 2014.

[15] Turan N G, Çoruh S, Akdemir A, Ergun O N, Münicipal solid waste management strategies in Turkey. Waste Management, 2008; 29, 465-469.

[16] Onurbaş Avcıoğlu A, Türker U, Demirel Atasoy Z, Koçtürk D. Tarımsal kökenli yenilenebilir enerjiler-biyoyakıtlar. Nobel Akademik Yayıncılık Eğitim Danışmanlık Tic. Ltd. Şti. Yayin No: 72, 493s, Ankara. 2011.

[17] FAO. Food losses and waste in Turkey, country report. Food and Agriculture Organization of the United Nations, 2013.

[18] The State Institute of Statistics, Prime Ministry, Republic of Turkey. Agricultural statistics, plant production. Ankara, State Institute of Statistics. 2015.

[19] Heffrich D, Oechsner H. Comparison of different laboratory techniques for the digestion of biomass. Landtechnik, 2003; 9: 27-30.

[20] VDI 4630. Fermentation of organic material, characterisation of substrate, collection of material data, fermentation tests, VDI Gesellschaft Energietechnik. 2006.

[21] AOAC. Official methods of analysis. 15th ed. Association of Official Analytical Chemists, Washington DC, US. 1990.

[22] Gül A. Determination of vegetables and fruit waste biogas production potential. Gazi Kocatepe University, Institute of Natural Sciences, Department of Environmental Sciences, Ankara, 2014

[23] VDI 4630-Richtlinie. Vergarung organischer Stoffe. VDI-Gesellschaft Energietechnik, Dusseldorf, 2006; 59.

[24] Lane A. Laboratory scale anaerobic digestion of fruit and vegetable solid waste. Biomass, 1984; 5: 245-259.

[25] Prema V, Sumithra S, Krishna N. Anaerobic of fruit and vegetable processing wastes for biogas production. Bioresource Technology, 1992; 40: 43-48.

[26] Mtz.-Viturtia A, Mata-Alverez J, Cecchi F. Two-phase continuous anaerobic digestion of fruit and vegetable wastes, resources. Conservation and Reycling, 1995; 13: 257-267.

[27] Bouallagui H, Ben Cheikh R, Marouani L, Hamdi M. Mesophilic biogas production from fruit and vegetable waste in tubular digester. Bioresource Technology, 2003; 86: 85-90.

[28] Qiao W, Yan X, Ye J, Sun Y, Wang W, Zhang Z. Evaluation of biogas production from different biomass wastes with/without hydrothermal pretreatment. Renewable Energy, 2011; 36: 3313-3318.

[29] Hutnan M, Spalkova V, Bodik I, Kolesarova N, Lazor M. Biogas production from maize and maize silage. Polish Journal of Environmental Studies, 2009; 19: 323-329.

[30] Frauke H K, Susanne O, Ebenhard H. Effect on the biogas and methane production of cattle manure treated with urease inhibition. Journal of Biomass and Bioenergy, 2015; 75-82. 